\title{
Haematological Profile of Dogs, Treated with Diminazene Aceturate Alone and Diminazene Plus Oxytetracycline, Long Acting
}

\section{Onyeachonam $\mathrm{FO}^{1 *}$, Onyeyili $\mathrm{PA}^{2}$ and Saganuwan $\mathrm{AS}^{2}$}

${ }^{1}$ Department of Veterinary Biochemistry and Animal Production, College of Veterinary Medicine, Michael Okpara University of Agriculture, Umudike, Nigeria

${ }^{2}$ Department of Veterinary Pharmacology and Toxicology, College of Veterinary Medicine Federal University of Agriculture, Makurdi, Nigeria

*Corresponding Author: Onyeachonam FO, Department of Veterinary Biochemistry and Animal Production, College of Veterinary Medicine, Michael Okpara University of Agriculture, Umudike, Nigeria.

DOI: 10.31080/ASVS.2022.03.0177
Received: June 08, 2021

Published: July 14, 2021

(C) All rights are reserved by Onyeachonam

FO., et al.

\begin{abstract}
For haematological profile of dogs treated with Diminazene aceturate (DA) alone and those treated with DA plus Oxytetracycline long acting (Oxytet LA), fourteen apparently healthy Nigerian indigenous dogs were assigned into two groups of seven dogs each. Blood samples were collected at different time intervals post treatment: $0,1,3,6,9,12,24,36$ and 48 hours. Means of PCV (26.63 \pm $\left.0.81^{\mathrm{a}} / 23.44 \pm 0.69^{\mathrm{b}}\right), \mathrm{Hb}\left(9.15 \pm 0.31^{\mathrm{a}} / 8.09 \pm 0.20^{\mathrm{b}}\right), \operatorname{TRBC}\left(4.10 \pm 0.16^{\mathrm{a}} / 3.70 \pm 0.15^{\mathrm{b}}\right)$, Neutrophils $\left(78.37 \pm 1.05^{\mathrm{a}} / 75.00 \pm 0.66^{\mathrm{b}}\right)$ and Eosinophils $\left(3.19 \pm 0.28^{\mathrm{a}} / 1.89 \pm 0.16^{\mathrm{b}}\right)$ were significantly $(\mathrm{P} \leq 0.05)$ higher in the group treated with DA alone than in the group treated with DA and Oxytet LA but means of the immune cells, Lymphocytes $\left(21.11 \pm 0.66^{\mathrm{a}} / 16.96 \pm 1.19^{\mathrm{b}}\right)$ and Monocytes $(2.00 \pm$ $\left.0.18^{\mathrm{a}} / 1.04 \pm 0.16^{\mathrm{b}}\right)$ were significantly higher $(\mathrm{P} \leq 0.05)$ in the group treated with DA and Oxytet LA than in the DA-alone group.
\end{abstract}

Keywords: Haematological Profile; Diminazene Aceturate; Oxytetracycline Long Acting; Dogs

\section{Introduction}

Nigerian indigenous dog is a breed native to Nigeria and are popularly referred to as "Mongrels" by indigenes. They are longheaded (dolichocephalic) domesticated dogs, with their feeding pattern being mainly omnivorous as a result of the increased level of domestication [1]. Presently, there are increasing numbers of this breed of dogs in Nigeria perhaps due to their resistance to certain haemoparasitic diseases such as canine babesiosis and trypanosomosis that constantly affect exotic breeds [2].

Diminazene aceturate (Berenil) has been the drug of choice for treatment of animal trypanosomosis since 1955. It is an aromatic diamidine consisting of two amidinophenyl moieties linked by a triazene bridge [3].

Oxytetracycline long acting, a tetracycline derivative obtained from Streptomyces rimosus, is a broad-spectrum antibiotic used against a variety of pathogens, including bacteria, mycoplasma, rickettsia, chlamydiae and even some protozoa [4].

Haematological parameters are those parameters that are related to the blood and blood forming organs [5]. Blood acts as a pathological reflector of the status of exposed animals to toxicant and other conditions [6]. Haematological profiles of dogs are essential in the diagnosis and monitoring of systemic diseases in Veterinary Medicine [7]. The examination of blood gives the opportunity to investigate the presence of several metabolites and other constituents in the body of animals and it plays a vital role in the physiological, nutrition and pathological status of an organism $[8,9]$. Due to the effects of several factors such as stress, age, sex, breeds, seasonal variations, climate, nutrition, treatments, housing and management system on the haematological parameters, changes in haematological parameters can thus be used to evaluate the effect of stressors and the deviation of an animal from the 
normal to the stress state [8], the evaluation of the nutritional state and the welfare of animals [10-12].

Some works had reported the haematology of the Nigeria local $\operatorname{dog}$ [2,13-16]. However, there is paucity of information on the effects of diminazene aceturate (DA) alone and its combination with oxytetetracycline long acting (oxytet LA) on the haematological profile of the Nigerian local dog. Since these two drugs are mostly used concomitantly in the treatment of typanosomosis in dogs and owing to the toxic effects they often produce in dogs, this work is designed to study the haematological picture of dogs treated with DA alone and its combination with oxytet LA.

\section{Materials and Methods}

Fourteen apparently healthy male Nigerian indigenous dogs aged between 4 to 6 months identified morphologically were used in this study. The dogs were presented to the Veterinary Teaching Hospital Michael Okpara University of Agriculture, Umudike, Abia state, Nigeria for clinical assessment of health and vaccination. This study was approved by the University of Agriculture, Makurdi Research and Ethics Committee. The study was conducted according to international guidelines [17]. Routine medical examination including haemoparasite screening was conducted on all dogs before sampling. Only clinically healthy dogs were sampled. Dogs having haemoparasites and external parasites were excluded. It was ensured that the dogs were calm prior to sampling. Age, sex, body weight, vital parameters and generalized body condition of the animals were assessed. For determination of haematological parameters, Diminazene aceturate was administered to group one through the left femoral vein at the rate of $3.5 \mathrm{mg} / \mathrm{kg}$ body weight using $7 \%$ solution. Blood samples were obtained from the right femoral vein. Oxytetracycline long acting was administered to group two at the right gluteal muscle deep intramuscularly at the rate of $20 \mathrm{mg} / \mathrm{kg}$ body weight, ten minutes after administration of diminazene aceturate $(3.5 \mathrm{mg} / \mathrm{kg}$ body weight), blood samples were obtained from the right femoral vein. Blood sample $(1 \mathrm{ml})$ was collected from the femoral vein of each dog using 23G needle and syringe. The blood sample was collected at different time intervals such as $0,1,3,6,9$, $12,24,36$ and 48 hours and each was dispensed into a tube containing ethylene diamine tetra acetic acid (EDTA) as an anticoagulant. All blood samples collected were analysed within ten minutes after collection. Red blood cell (RBC) counts were determined using a haemocytometer. The packed cell volume (PCV) was estimated by the micro haematocrit method and haemoglobin ( $\mathrm{Hb})$ concentration by the cyanmethaemoglobin method. The mean corpuscular volume (MCV) and mean corpuscular haemoglobin (MCH) and mean corpuscular haemoglobin concentration (MCHC) were calcu- lated as described by Coles [18] and Esievo [16, 19].

Statistical analysis

The data collected were analysed using SPSS version 20 statistical package. All data were expressed as Means \pm Standard Error of Means (S.E.M). Students ' $\mathrm{t}$ ' test was used to compare the two groups which are DA alone and DA plus oxytet LA. Least significant difference was dictated at 5\% significance level.

\section{Results}

Mean-PCV (26.63 $\pm 0.81 \mathrm{a})$, HB $(9.15 \pm 0.13 \mathrm{a})$, TRBC $(4.10 \pm$ $0.16 \mathrm{a})$, Neutrophils $(78.37 \pm 1.05 \mathrm{a})$ and Eosinophil $(3.19 \pm 0.16 \mathrm{a})$ of the group treated with DA alone were significantly ( $\mathrm{P} \leq 0.05)$ higher than $23.44 \pm 0.69 b, 8.09 \pm 0.29 b, 3.70 \pm 0.15 b, 75.00 \pm 0.66 b$ and $1.89 \pm 0.18 \mathrm{~b}$ of the group treated with DA plus Oxytet LA respectively but mean- Lymphocytes $(21.11 \pm 0.61 \mathrm{a})$ and Monocytes $(2.00 \pm 0.18 \mathrm{a})$ of the group of DA plus Oxytet LA were significantly $(\mathrm{P} \leq 0.05$ ) higher than $16.96 \pm 1.19 \mathrm{~b}$ and $1.04 \pm 0.16 \mathrm{~b}$ of the DA alone-group respectively while there were no significant differences $(P \geq 0.05)$ in means of WBC $(2.83 \pm 0.28 \mathrm{a} \& 3.40 \pm 0.26 \mathrm{a})$, MCV (62.11 $\pm 0.73 \mathrm{a} \& 64.26 \pm 1.08 \mathrm{a}), \mathrm{MCH}(21.33 \pm 0.35 \mathrm{a} \& 22.30 \pm 0.52 \mathrm{a})$, MCHC (34.33 $\pm 2.19 \mathrm{a} \& 34.78 \pm 0.04 \mathrm{a})$ and Basophils $(0.07 \pm 0.03 \mathrm{a} \&$ $0.00 \pm 0.00 \mathrm{a}$ ) between the two groups, see (Table 1 ).

\begin{tabular}{|c|c|c|}
\hline Haematological parameter & DA & DA+LA \\
\hline PCV & $26.63 \pm 0.81^{\mathrm{a}}$ & $23.44 \pm 0.69^{\mathrm{b}}$ \\
\hline Hb & $9.15 \pm 0.31^{\mathrm{a}}$ & $8.09 \pm 0.20^{\mathrm{b}}$ \\
\hline TRBC & $4.10 \pm 0.16^{\mathrm{a}}$ & $3.70 \pm 0.15^{\mathrm{b}}$ \\
\hline WBC & $2.83 \pm 0.28^{\mathrm{a}}$ & $3.40 \pm 0.26^{\mathrm{a}}$ \\
\hline MCV & $62.11 \pm 0.73^{\mathrm{a}}$ & $64.26 \pm 1.08^{\mathrm{a}}$ \\
\hline MCH & $21.33 \pm 0.35^{\mathrm{a}}$ & $22.30 \pm 0.52^{\mathrm{a}}$ \\
\hline MCHC & $34.33 \pm 2.19^{\mathrm{a}}$ & $34.78 \pm 0.40^{\mathrm{a}}$ \\
\hline Neutrophils & $78.37 \pm 1.05^{\mathrm{a}}$ & $75.00 \pm 0.66^{\mathrm{b}}$ \\
\hline Lymphocytes & $16.96 \pm 1.19^{\mathrm{b}}$ & $21.11 \pm 0.66^{\mathrm{a}}$ \\
\hline Eosinophils & $3.19 \pm 0.28^{\mathrm{a}}$ & $1.89 \pm 0.16^{\mathrm{b}}$ \\
\hline Monocytes & $1.04 \pm 0.16^{\mathrm{b}}$ & $2.00 \pm 0.18^{\mathrm{a}}$ \\
\hline Basophils & $0.07 \pm 0.05^{\mathrm{a}}$ & $0.00 \pm 0.00^{\mathrm{a}}$ \\
\hline
\end{tabular}

Table 1: Haematological parameters of dogs treated with Diminazine aceturate alone and with Diminazine aceturate plus long acting Oxytetracycline.

PCV - Packed cell volume, Hb - Haemoglobin, RBC - Red blood cell count, MCV - Mean corpuscular volume, MCHC - Mean corpuscular haemoglobin volume, WBC - Total white blood cell count. Where ${ }^{\text {a }}$ $=\mathrm{P}<0.05$ is significantly higher, ${ }^{\mathrm{b}}=\mathrm{P}<0.05$ and where there is a on both groups $=\mathrm{P}>0.05$; indicates not significant $(\mathrm{P}>0.05)$. 


\section{Discussion}

Compared to reference values/range for Nigerian indigenous dogs haemoglobin concentration (Hb), packed cell volume (PCV) and total red blood cell count (TRBC) decreased significantly in dogs treated with DA plus oxytetracycline long acting and were below the lower reference values $[15,16]$ but TRBC was still within the lower reference range though lower than the mean of the group that was not treated with Oxyt-LA. This suggests that concurrent treatment of sick dogs with DA and oxytet LA may worsen anaemia (regenerative). Such condition of regenerative anaemia could lead to inadequate tissue oxygenation and anaemia [20-23].

Diminazine aceturate is the drug of choice for treatment of canine trypanosmosis in Nigeria [3]. The drug is also often supported with antibiotics to treat secondary bacterial infections because trypanosmosis is associated with immune deficiency [24]. Most clinicians prefer Oxytetracyline long acting to Oxyt-short acting because of its (Oxytet LA) broad spectrum activity, relatively lower cost [4] and the continence of treating once in three days instead of daily treatment. However, results of this study appear/suggest worsening of anaemia as a side effect of such concurrent treatment of dogs with DA plus Oxytet LA.

We therefore suggest that whenever dogs are to be treated with DA and Oxytet LA supportive treatments including haematinics (blood products) should be included in the protocol in order to maintain Hb concentration and PCV within normal limits.

There was no significant differences in the means of WBC, MCV, $\mathrm{MCH}$ and MCHC between the two groups and their values were within the reference range for Nigerian indigenous dogs [16] and White blood cells counts and its differentials are measures of immunity. The cells fight infections to defend the body by phagocytosis and they produce or at least transport and distribute antibodies. Animals with low white blood cells are exposed to high risk of disease infections [25]. So, the results show that use of diminazene aceturate alone or in combination with oxytetracycline long acting may not on their own cause immune deficiency. However, it is suggested that immune boosters be given to dogs undergoing treatment.

There were significant increases $(\mathrm{p}<0.05)$ in neutrophils and eosinophils in the group treated with DA alone when compared with reference values and the group of dogs treated with DA plus oxytet LA. Neutrophilia is usually caused by inflammation while
Eosinophilia suggests allergy [26]. The results therefore suggest that treatment with DA alone causes more inflammatory reactions and allergic reactions in dogs than combining it with oxytet LA. Again, supporting the treatment with antioxidant is suggested.

\section{Conclusion}

Haematological parameters and its knowledge can be used to assess the health, study the effects of drugs as well as the physiological status of animals under treatment. From this study we recommend that the use of Diminazene aceturate to treat dogs, either alone or concurrently with Oxytetracycline (long acting) should be supported with haematinics and antioxidants.

\section{Conflict of Interest}

There is no conflict of interest among the authors.

\section{Bibliography}

1. Igado 00. "Neurometrics and neurocraniometry of Nigerian local dog (Canis lupus familiaris)". Journal of Veterinary Anatomy 4 (2011): 99 - 109.

2. Olayemi FO., et al. "Study on erythrocyte values of the Nigerian indigenous dog". Folia Veterinaria 53 (2009): 65-67.

3. Peregrine AS and Mamman M. "Pharmacology of diminazene: a review". Acta Tropica 54 (1993): 185-203.

4. Bywater RJ. "Veterinary Applied Pharmacology and Therapeutics". Bailliere Tindal London, UK (1991).

5. Waugh A., et al. "Anatomy and Physiology in Health and Illness". (9th ed). Churchill Livingston, an imprint of Elsevier Science Limited (2001): 59-71

6. Olafedehan CO., et al. "Effects of residual cyanide in processed cassava peal meals on haematological and biochemical indices of growing rabbits". Proceedings of $35^{\text {th }}$ Annual conference of Nigerian Society for Animal Production (2010): 212.

7. Chang YM., et al. "Serum biochemical phenotypes in the domestic dogs". PLoS One 11 (2016): 0149650.

8. Aderemi FA. "Effects of replacement of wheat bran with cassava root sievate supplemented or unsupplemented with enzyme on the haematology and serum biochemistry of pullet chicks". Tropical Animal Science Journal 7 (2004): 147-153. 
9. Doyle D William Hewson (1739-74). "The father of haematology”. British Journal of Haematology 133.4 (2006): 375-381.

10. Jain NC. "Essentials of Veterinary Hematology". Lea and Febiger, Philadelphia, U.S.A (1993).

11. Khan TA and Zafar F. "Haematological study in response to various doses of oestrogen in broiler production". International Journal of Poultry Science 40.10 (2005): 748-751.

12. Etim NN., et al. "Haematological Parameters and Factors Affecting their Values". Agricultural Science 2.1 (2014): 37-47.

13. Saror DI., et al. "The haemogram of dogs with intestinal parasites in Zaria, Nigeria". Journal of Small Animal Practice 20 (1979): 243-247.

14. Ariyibi AA., et al. "A Comparative Study of Some Hematology and Biochemical Parameters of Clinically Healthy Alsatian and Local Dogs". African Journal Biomedical Research 5 (2002): 145-147.

15. Adekola AA., et al. "Baseline Haematology and Erythrocyte Morphological Changes of Apparently Normal Dogs Raised in Ibadan, Oyo State". Nigerian Journal of Physiological Sciences 30 (2015) 111-118.

16. Atata JA., et al. "Baseline haematological, serum biochemical and some urine parameters in Nigerian indigenous dogs". Savannah Veterinary Journal 1 (2018): 1-5.

17. Wolfensohn S and Lloyd M. "Handbook of Laboratory Animal Management and Welfare". 4th edition. Wiley- Blackwell Publishing Ltd, UK; (2013): 371.

18. Coles EH. "Veterinary Clinical Pathology". 1st Edition. W.B. Saunders Company Ltd. Philadelphia. London; (1980): 156193.

19. Esievo KAN. "Veterinary Clinical Pathology". 1st Edition. Spectrum Books Ltd, Ibadan; (2017): pp. 143-144.

20. Billet HH. Hb and Hematocrit in Walker HK, Hall WD, Hurst JW, edition- clinical methods: The History, physical and laboratory examination; $3^{\text {rd }}$ edition: (1990). chapter 151.
21. Feldman BF., et al. "Schalm's Veterinary Haematology". 5th edition, Philadelphia, PA; Lippincott Williams and wilkins (2000).

22. Purves WK., et al. "Life: The science of Biology". 7th edition, Sinauer Associates and W. H. Freeman. (2003): 954.

23. Nelson RW and Couto CG. "Small Animal internal medicine". 4th edition St louis, MO: Mosby-Elsevier. (2009).

24. Nyakundi JN., et al. "The relationships between intestinal damage and circulating endotoxins in experimental Trypanosoma brucei brucei infections". Parasitology 124 (2002): 589-595.

25. Soetan KO., et al. "Preliminary studies on the haematological parameters of cockrels fedraw processed ginea corn (Sorghum bicolor)". Proceedings of 38th Annual Conference of Nigerian Society of Animal Production (2013): 49-52.

26. Wood RD. "White Blood Cell Disorders of Dogs". Ontario Veterinary College, University of Guelph. MSD Manual Veterinary Manual (2017).

\section{Assets from publication with us}

- Prompt Acknowledgement after receiving the article

- Thorough Double blinded peer review

- Rapid Publication

- Issue of Publication Certificate

- High visibility of your Published work

Website: www.actascientific.com/

Submit Article: www.actascientific.com/submission.php

Email us: editor@actascientific.com

Contact us: +919182824667

Citation: Onyeachonam FO., et al. "Haematological Profile of Dogs, Treated with Diminazene Aceturate Alone and Diminazene Plus Oxytetracycline, Long Acting". Acta Scientific Veterinary Sciences 4.3 (2022): 11-14. 